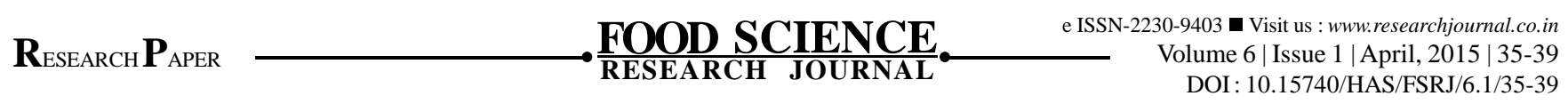

\title{
Development and sensory evaluation of value added products
}

\author{
Vinita Singh and Anjali Verma
}

\begin{abstract}
Maize is used as food, as feed for livestock and as raw material for industry The level of incorporation in developed products were $\mathrm{T}_{1}(20 \%), \mathrm{T}_{2}(40 \%), \mathrm{T}_{3}(60 \%)$ and $\mathrm{T}_{4}(80 \%)$. These products were analyzed for its organoleptic acceptability by panel members. This revealed that 60 per cent incorporated Laddoos and 60 per cent incorporated Namkeen had better quality in terms of taste and flavour, body and texture, colour and appearance and overall acceptability than control and other incorporated products. Analysis of variance revealed that 60 per cent incorporated Laddoos was liked extremely while 60 per cent incorporated namkeen was liked very much.
\end{abstract}

Key Words : Zea mays, Organolepetic acceptability, Laddoos Namkeen

How to cite this article : Singh, Vinita and Verma, Anjali (2015). Development and sensory evaluation of value added products. Food Sci. Res. J., 6(1): 35-39.

VINITA SINGH, Department of Food Science and Nutrition, College of Home Science, C.S.A. University of Agriculture and Technology, KANPUR (U.P.) INDIA Associate Authors' :

ANJALI VERMA, Department of Food Science and Nutrition, College of Home Science, C.S.A. University of Agriculture and Technology, KANPUR (U.P.) INDIA 